\title{
Hubungan Usia, Lama Pendidikan, Pekerjaan, dan Paritas Ibu Dengan Tingkat Kepatuhan ANC di RSUD Syekh Yusuf Kabupaten Gowa Tahun 2018
}

\section{Najamuddin Andi Palancoi ${ }^{1}$, Yusril Ihsanul $M^{* 2}$, Azizah Nurdin ${ }^{3}$}

${ }^{1}$ Departemen Biomedik, Fakultas Kedokteran dan Ilmu Kesehatan, UIN Alauddin Makassar

${ }^{2}$ Departemen Program Studi Sarjana Kedokteran, Fakultas Kedokteran dan Ilmu Kesehatan, UIN Alauddin Makassar

${ }^{3}$ Departemen Obsetri dan Ginekologi, Fakultas Kedokteran dan Ilmu Kesehatan, UIN Alauddin Makassar *Corresponding Author. E-mail: yusrilihsanulmukarram@gmail.com Mobile number: 081243849959

\begin{abstract}
ABSTRAK
Latar Belakang: : ANC atau Antenatal Care merupakan suatu pelayanan oleh tenaga kesehatan yang memenuhi standard yang sesuai kepada ibu hamil untuk memeriksa kondisi kehamilannya. Ibu hamil dapat patuh melakukan ANC disebabkan oleh banyak faktor seperti diantaranya adalah usia ibu saat hamil, lama pendidikan yang sudah ditempu, status pekerjaan, dan paritas ibu hamil. Tujuan penelitian ini adalah untuk mengetahui apakah ada hubungan usia, lama pendidikan, status pekerjaan, dan paritas ibu dengan tingkat kepatuhan ANC.

Hasil: Design penelitian ini adalah analitik retrospektif dengan menggunakan pendekatana Cross-sectional. Populasi penelitian ini yaitu semua ibu hamil yang mengalami komplikasi berupa perdarahan postpartum kemudian melihat bagaiman kepatuhan kepatuhan ANC ibu tersebut berdasarkan dari rekam medik RSUD Syekh Yusuf pada Tahun 2018. Teknik pengambilan sampel penelitian ini yaitu total sampling.

Kesimpulan: Terdapat hubungan antara status pekerjaan ibu hamil dengan kepatuhan ANC.

Kata Kunci: Antenatal care; Usia; Lama Pendidikan; Pekerjaan; dan Paritas Ibu
\end{abstract}

Article history:

Received: 10 April 2021

Accepted: 30 April 2021

Published: 30 Juni 2021

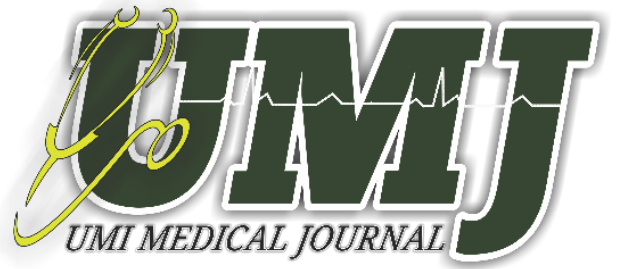

Published by :

Fakultas Kedokteran

Universitas Muslim Indonesia

Phone:

+6282293330002
Address:

Jl. Urip Sumoharjo Km. 5 (Kampus II UMI)

Makassar, Sulawesi Selatan.

Email:

medicaljournal@umi.ac.id 


\section{ABTRACT}

Background: ANC or Antenatal Care is a service provided by health professionals who meet the appropriate standards for pregnant women to check the condition of their pregnancy. Pregnant women can comply with ANC because of many factors such as the age of the mother during pregnancy, the length of education that has been taken, the status of work, and the parity of pregnant women. The purpose of this study was to determine whether there was a relationship between age, length of education, employment status, and maternal parity with ANC compliance levels.

Results The design of this study was a retrospective analytic using a cross-sectional approach. The populations of this study were all pregnant women who experienced complications in the form of postpartum hemorrhage and then saw how the mother's ANC compliance was based on the medical records of Syekh Yusuf Hospital in 2018. The sampling technique for this study was total sampling.

Conclusion: Oxidative stress in obesity causes cell damage which plays an important role in the pathogenesis of various degenerative disease such as diabetes mellitus, hypertension, the aging process, and cancer.

Keywords: Obesity; Oxidative stress

\section{PENDAHULUAN}

Kementerian kesehatan republik Indonesia memiliki upaya meningkatkan kualitas kesehatan ibu dan juga anak dengan cara menekan kematian dan kesakitan ibu dan juga anak.(1) Pada tahun 2015 pada sebuah studi yang dilakukan oleh WHO didapatkan angka kematian ibu diseluruh dunia sebanyak 304.000 atau 238/100.000 kelahiran hidup selama atau setelah persalinan.(2) Pada tahun 2015 angka kematian ibu di Indonesia bahwa lebih besar dibandingkan angka kematian secara global yaitu 305/100.000 kelahiran hidup.(3) Kemudian privinsi Sulawesi Selatan didapatkan angka kematian ibu pada 2016 yaitu sebanyak 153 orang atau 103/100.000 kelahiran hidup.(4)

Tingginya angka ini disebabkan beberapa hal dan dalam studi yang dilakukan kementerian kesehatan memaparkan beberapa penyebab yang menjadi faktor risiko terjadinya AKI yaitu perdarahan selama dan juga sesudah ibu melahirkan, infeksi selama kehamilan, tekanan darah tinggi saat hamil hamilan, partus lama, dan abortus.(3) Dari sekian banyak penyebab diatas, 30,3 \% adalah karena perdarahan dan jenis perdarahan yang banyak adalah perdarahan postpartum.(5) Di Indonesia, didaptkan bahwa kematian ibu hamil $28 \%$ disebabkan oleh perdarahan dan terbanyak yaitu perdarahan postpartum.(6) Pada tahun 2018 di RSUD Syekh Yusuf, didapatkan jumlah pasien dengan perdarahan postpartum sebanyak 82 kasus.

Kejadian perdarahan postpartum ini sebenarnya dapat di cegah dan salah satu pencegahannya adalah dengan melakukan pemeriksaan kesehatannya saat hamil secara rutin yang disebut dengan Antenatal care (ANC). ANC bagi ibu hamil sangat penting karena dengan melakukan ANC ibu hamil dapat mencegah terjadinya penyakit-penyakit yang dapat membahayakan kehamilannya.(7) Pentingnya ANC ini sayangnya masih belum terlalu dipahami oleh kebanyakan orang sehingga masih cenderung memiliki niat dan minat yang kurang untuk melakukan ANC.(3) 
UMI Medical Journal Vol.6 Issue:1 (Juni, 2021)

p-ISSN: 2548-4079/e-ISSN: 2685-7561

Berdasarkan masalah yang dijelaskan di atas, kami tertarik untuk meneliti untuk mengetahui apakah terdapat hubungan antara tingkat kepatuhan ANC dengan usia, lama pendidikan, pekerjaan, dan paritas pada semua kasus perdarahan postpartum.

\section{METODE}

Metode penelitian yang digunakan adalah analitik retrospektif dengan pendekatan cross sectional. Tujuan penelitian ini adalah untuk mengetahui hubungan kepatuhan ANC dengan usia, pekerjaan, lama pendidikan, dan paritas ibu. Penelitian ini dilakukan pada Januari 2020 RSUD Syekh Yusuf Gowa dan telah mendapatkan kelaikan etik yaitu E.011/KEPK/FKIK/XII/2019 para tanggal 18 Desember 2019. Populasi dalam penelitian ini yaitu semua ibu yang mengalami komplikasi berupa perdarahan postpartum di RSUD Syekh Yusuf Gowa pada tahun 2018. Teknik penentuan sampel yang digunakan adalah total sampling yaitu sebanyak 82 sampel.

Data yang digunakan pada penelitian ini bersumber dari data sekunder yang diperoleh dari rekam medik di RSUD Syekh Yusuf Gowa. Data yang didapatkan kemudian dianalisis menggunakan software IBM SPSS 23. Dan untuk Analisis hubungan antara variabel menggunakan uji Chi-Square.

\section{HASIL}

Tabel 1. Distribusi Sampel Berdasarkan Karakteristik Sampel

\begin{tabular}{lcc}
\hline \multicolumn{1}{c}{ Parameter } & $\mathbf{N}$ & $\%$ \\
\hline Usia & 8 & \\
a. $\quad 20$ tahun & 74 & 9,8 \\
b. $20-35$ tahun & & \\
\hline Lama Pendidikan & 14 & 17,1 \\
a. $\leq 9$ tahun & 68 & 82,9 \\
b. >9 tahun & & \\
\hline Status pekerjaan & 35 & 42,68 \\
a. Bekerja & 47 & 57,32 \\
b. Tidak Bekerja & & \\
\hline Paritas $\quad 35$ & 42,68 \\
a. Primipara & 47 & 57,32 \\
b. Multipara & & 21,95 \\
\hline Antenatal Care (ANC) & 18 & 78,05 \\
c. Patuh & 64 & \\
a. Tidak Patuh & & \\
\hline
\end{tabular}

Berdasarkan Tabel 1, didapatkan dari total 82 sampel, distribusi sampel berdasarkan usia saat hamil didaptkan mayoritas sampel berusia 20-35 tahun yaitu 74 orang $(90,2 \%)$ dan sampel yang berusia $<20$ tahun yaitu 8 orang $(9,8 \%)$. Distribusi sampel berdasarkan lama pendidikan pada sampel didaptkan mayoritas sampel memiliki lama pendidikan > 9 tahun yaitu 68 orang $(82,9 \%)$, dan yang memiliki lama pendidikan $\leq 9$ tahun sebanyak 14 orang $(17,1 \%)$. Kebanyakan sampel berdasarkan status pekerjaan ibu lebih banyak yang tidak memiliki pekerjaan yaitu 47 orang (57,32\%), sedangkan ibu yang memiliki pekerjaan sebanyak 35 orang (42,68\%). Mayoritas sampel berdasarkan paritas ibu hamil lebih banyak 
UMI Medical Journal Vol.6 Issue:1 (Juni, 2021)

p-ISSN: 2548-4079/e-ISSN: 2685-7561

yang multipara yaitu 47 orang $(57,32 \%)$, sedangkan ibu yang primipara sebanyak 35 orang $(42,68 \%)$.

Untuk distribusi sampel dengan kepatuhan ANC didaptkan kebanyakan sampel tidak patuh daam melakukan pemeriksaan ANC yaitu sebanyak 64 orang $(78,05 \%)$, dan sampel yang patuh dalam melakukan pemeriksaan ANC sebanyak 18 orang $(21,95)$.

Tabel 2. Analisis Hubungan Usia dengan Kepatuhan ANC

\begin{tabular}{|c|c|c|c|c|c|}
\hline \multirow[t]{2}{*}{ Usia } & \multicolumn{2}{|c|}{ ANC } & \multirow{2}{*}{$\begin{array}{c}\text { Total } \\
\text { (n) }\end{array}$} & \multirow[t]{2}{*}{$\%$} & \multirow[t]{2}{*}{ P-Value } \\
\hline & Patuh & Tidak & & & \\
\hline$<20$ tahun & 4 & 4 & 8 & 9,8 & \\
\hline $20-35$ tahun & 14 & 60 & 74 & 90,2 & 0,066 \\
\hline Total & 18 & 64 & 82 & 100 & \\
\hline
\end{tabular}

Berdasarkan Tabel 2, didapatkan bahwa dari hasil analisis hubungan antara usia ibu saat hamil dengan kepatuhan ANC menggunakan uji chi-square didapatkan hasil sebesar 0,066 (> 0,05). Hasil ini menunjukkan bahwa tidak ada hubungan antara usia dengan tingkat kepatuhan ANC.

Tabel 3. Analisis Hubungan Lama pendidikan dengan Kepatuhan ANC

\begin{tabular}{lcccccc}
\hline Lama Pendidikan & \multicolumn{2}{c}{ ANC } & & Total & $\%$ & P-Value \\
\cline { 2 - 4 } & Patuh & Tidak & & (n) & & \\
\hline$\leq 9$ tahun & 1 & 13 & 14 & 17,1 & \multirow{2}{*}{0,285} \\
\hline$>9$ tahun & 17 & 51 & 68 & 82,9 & \\
\hline Total & 18 & 64 & 82 & 100 & \\
\hline
\end{tabular}

Berdasarkan Tabel 3, didapatkan hasil analisis hubungan antara lama pendidikan dengan kepatuhan ANC menggunakan uji chi-square didapatkan hasil sebesar 0,285 (> 0,05). Hasil ini menunjukkan tidakadanya hubungan yang signifikan antara lama pendidikan terhadap tingkat kepatuhan ANC.

Tabel 4. Analisis Hubungan pekerjaan dengan Kepatuhan ANC

\begin{tabular}{lcccccc}
\hline \multirow{2}{*}{ Pekerjaan } & \multicolumn{2}{c}{ ANC } & & $\begin{array}{c}\text { Total } \\
\text { (n) }\end{array}$ & \% & P-Value \\
\cline { 2 - 3 } & Patuh & Tidak & & \multirow{2}{*}{0,000} \\
\cline { 1 - 5 } Tidak Bekerja & 2 & 45 & 47 & 57,32 & \\
\hline Bekerja & 16 & 19 & 35 & 42,68 & \\
\hline Total & 18 & 64 & 82 & 100 & \\
\hline
\end{tabular}

Berdasarkan Tabel 4, didapatkan hasil analisis hubungan antara status pekerjaan ibu hamil dengan kepatuhan ANC menggunakan uji chi-square didapatkan hasil sebesar 0,000 $(<0,05)$. Hasil ini menunjukkan adanya hubungan yang signifikan antara status pekerjaan ibu hamil dengan tingkat kepatuhan ANC.

Tabel 5. Analisis Hubungan paritas dengan Kepatuhan ANC

\begin{tabular}{lcccccc}
\hline \multirow{2}{*}{ Paritas } & \multicolumn{2}{c}{ ANC } & & Total & $\%$ & P-Value \\
\cline { 2 - 3 } & Patuh & Tidak & & (n) & & \\
\hline Primipara & 11 & 24 & & 35 & 42,68 & \\
\hline
\end{tabular}


UMI Medical Journal Vol.6 Issue:1 (Juni, 2021)

p-ISSN: 2548-4079/e-ISSN: 2685-7561

\begin{tabular}{lccccc}
\hline Multipara & 7 & 40 & 47 & 57,32 & 0,129 \\
\cline { 1 - 4 } Total & 18 & 64 & 82 & 100 & \\
\hline
\end{tabular}

Berdasarkan Tabel 5, didapatkan hasil analisis hubungan antara paritas ibu dengan kepatuhan ANC menggunakan uji chi-square didapatkan hasil sebesar 0,129 (>0,05). Hasil yang ini menunjukkan tidak adanya hubungan yang signifikan antara paritas ibu hamil dengan tingkat kepatuhan ANC.

\section{PEMBAHASAN}

Antenatal Care adalah program yang dilakukan oleh petugas kesehatan professional untuk memberikan pelayanan kesehatan bagi ibu hamil untuk mengurangi angka morbiditas dan mortalitas ibu dan anak.(3)

Tingkat keberhasilan kepatuhan ANC dipengaruhi oleh banyak faktor yaiut usia ibu, lama pendidikan, pekerjaan dan juga paritas ibu. Dapat dilihat pada tabel 2, didapatkan hasil uji sebesar 0,066 yang menjelasakan bahwa tidak terdapat hubungan antara usia dengan kepatuhan ANC. Hasil penelitian ini sejalan dengan penelitian yang dilakukan oleh Ayu Indah Rachmawati pada tahun 2017 diaman hasil penelitian yang didapatkan adalah terdapat hubungan antara usia ibu hamil dengan kepatuhan ANC.(8) Namun Hasil pada pnelitian ini tidak sejalan dengan penelitian yang dilakukan oleh Mira pada tahun 2014 yang menyebutkan bahwa ada hubunga tentang usia ibu hamil dengan Kepatuham ANC.(9)

Kelengkapan seorang ibu dalam melakukan pemeriksaan pada dasarnya dapat disebabkan oleh usia. Semakin tua usia seorang ibu maka akan semakin dewasa pula pemikirannya sehingga dengan kedewasaan pemikiran membuat dia lebih bijak dalam mengambil sebuah keputusan termasuk adalah untuk selalu memeriksakan kesehatan kandungannya. Dengan demikian, ibu dengan usia yang lebih dewasa akan lebih berpotensi memiliki ANC yang patuh dibandingkan usia yang lebih mudah.(8)

Pada tabel 3, dapat dilihat bahwa dari hasil pengujian hubungan didapatkan nilai $p$-value sebesar 0,285 yang menunjukkan bahwa tidak terdapat hubungan antara lama pendidikan dengan kepatuhan ANC.(10) Hasil ini sejalan dengan penelitian sebelumnya yang dilakukan oleh Mohdari, pada tahun 2014 di Puskesmas Pekauman Banjarmasin dimana di dalam penelitian yang dilakukan, didapatkan kebanyakan sampel memiliki riwayat penidikan SMP yaitu sebanyak 18 orang. Dan setelah dilakukan pengujian didapatkan hasil > 0,05 yang menandakan tidak adanya hubungan antara pendidikan ibu dengan kepatuhan ANC.

Penelitian ini tidak sejalan dengan penelitian yang dilakukan oleh Fitrayeni pada tahun 2015 yang mendapatkan hubungan yang sangat bermakna antara tingkat pendidikan dengan kelengkapan ANC. Tingkat pendidikan formal yang lebih tinggi akan lebih mempunyai pengetahuan dan kesadaran yang luas terkait segala hal termasuk kesehatan sehingga seorang ibu hamil dengan tingkat pendidikan tinggi akan lebih bersemangat dan antusias dibandingkan ibu dengan tingkat pendidikan yang lebih rendah. Yang termasuk didalam pendidikan formal adalah riwayat pendidikan yang dijalani seorang ibu secara 
UMI Medical Journal Vol.6 Issue:1 (Juni, 2021)

p-ISSN: 2548-4079/e-ISSN: 2685-7561

terstruktur dan terorganisir. Pendidikan $\leq 9$ tahun termasuk diantaranya adalah sekolah dasar dan sekolah menengah pertama sedangkan untuk pendidikan > 9 tahun adalah SMA dan bangku perkuliahan.(11)

Tabel 4 menunjukkan bahwa terdapat hubungan yang signifikan antara status pekerjaan ibu dengan kepatuhan ANC dimana nilai p-value yang didapatkan adalah 0,000 $(<0,05)$. Hasil ini sesuai dengan penelitian sebelumnya yang dilakukan oleh Mira pada tahun 2014 yang menunjukkan bahwa terdapat hubungan anatar status pekerjaan ibu hamil dengan kelengkapan ANC. Pada penelitiannya juga menjelskan bahwa Ibu hamil yang memiliki pekerjaan akan lebih berpotensi memiliki ANC yang lengkap dibandingkan dengan ibu yang tidak bekerja.(9)

Ibu yang memiliki pekerjaan biasanya akan lebih patuh melakukan ANC dibandingkan dengan ibu yang tidak bekerja. Hal ini disebabkan karena pada ibu yang memiliki pekerjaan, ibu tersebut akan mempunyai biaya untuk menjangkau dan melakukan pemeriksaan ANC. Sedangkan ibu yang tidak bekerja cenderung akan tidak mempunyai biaya dalam menjangkau fasilitas kesehatan. Selain itu, dengan bekerja seorang ibu hamil akan lebih banyak mendapatkan saran dan informasi terkait kesehatan kehamilan sehingga dapat lebih termotivasi dalam melakukan pemeriksaan ANC.(9)

Tabel 5, dapat dilihat hasil uji hubungan antara paritas ibu dengan kepatuhan ANC didapatkan nilai p-value sebesar 0,129 yang menunjukkan bahwa tdak ada hubungan yang signifikan. Hasil penelitian ini berbeda dengan penelitian yang dilakukan oleh Manisti pada tahun 2017 dimana hasil penelitiannya adalah terdapat hubungan antara jumlah paritas dengan kelengkapan ANC.(12)

Seseorang dengan kehamilan pertama akan lebih giat dalam melakukan pemeriksaan kesehatan saat dia hamil dibandingkan ibu hamil yang sudah memiliki banyak anak. Hal ini terjadi karena ibu dengan kehamilan pertama masih tidak mengetaui tentang hal hal yang harus dilakukan selama kehamil selain itu diaa juga masih belumtahu tentang bagaimna perubahan fisiologis yang dirasakannya sehingga cenderung akan selalu takut dengan hal - hal baru yang membuat dia akan datang ke tenaga kesehatan untuk melakukan pemeriksaan rutin. berbeda dengan ibu dengan jumlah anak yang sudah banyak, dia cenderung akan menganggap bahwa sudah tahu tentang segalah sesuatu yang harusnya dilakukan selama kehamilannya selain itu dia juga sudah terbiasa mendapatkan keluhan keluhan kecil sehingga cederung akan lebih malas dalam melakukan pemeriksaan ANC.(13)

\section{KESIMPULAN DAN SARAN}

Berdasarkan hasil penelitian maka dapat disimpulkan bahwa terdapat hubungan signifikan antara status pekerjaan ibu dengan tingkat kepatuhan ANC. Namun, tidak terdapat hubungan antara usia, lama pendidikan, dan paritas ibu dengan kelengkapan ANC. 
UMI Medical Journal Vol.6 Issue:1 (Juni, 2021)

p-ISSN: 2548-4079/e-ISSN: 2685-7561

\section{DAFTAR PUSTAKA}

1. Kementerian kesehatan Republik Indonesia. Imunisasi Massal Campak dan Rubella diberikan pada anak usia 9 bulan, kurang dari 15 Tahun pada bulan Agustus di Sekolah dan September di Puskesmas P dan FKP tahun 2017 di PJ dan 2018 di luar J 2018Kemenkes. Kementerian Kesehatan Republik Indonesia. Kementeri Kesehat RI [Internet]. 2019;1. Available from: https://www.kemkes.go.id/article/view/19093000001/penyakit-jantung-penyebab-kematianterbanyak-ke-2-di-indonesia.html

2. WHO. Maternal mortality Evidance brief. Matern Mortal [Internet]. 2017;(1):1-4. Available from: https://apps.who.int/iris/bitstream/handle/10665/329886/WHO-RHR-19.20-eng.pdf?ua=1

3. Kementerian Kesehatan Republik Indonesia. Profil Kesehatan Indonesia 2016 [Internet]. Profil Kesehatan Provinsi Bali. 2016. 1-220 p. Available from: http://www.depkes.go.id/resources/download/pusdatin/profil-kesehatan-indonesia/Profil-KesehatanIndonesia-2016.pdf

4. dinas kesehatan provinsi sulawesi selatan. Profil kesehatan provinsi sulawesi selatan tahun 2016 . dinas Kesehat provinsi sulawesi selatan. 2017;

5. Ramadhan JW, Rasyid R, Rusnita D. Profil Pasien Hemorrhagic Postpartum di RSUP Dr. M. Djamil Padang. J Kesehat Andalas. 2019;8(2S):46.

6. Ludyaningrum RM. PERILAKU BERKENDARA DAN JARAK TEMPUH DENGAN KEJADIAN ISPA PADA MAHASISWA UNIVERSITAS AIRLANGGA SURABAYA Driving Behavior and Mileage with the Incidence of URI on Students at Universitas Airlangga Surabaya. J Berk Epidemiol. 2016;4(3):384-95.

7. Puspitasari R, Hastuti URB, Murti B. Faktor risiko perdarahan postpartum diKabupaten Bondowoso Jawa Timur. J Matern Child Heal. 2017;2:177-87.

8. Rachmawati AI, Puspitasari RD, Cania E. Faktor-faktor yang Memengaruhi Kunjungan Antenatal Care ( ANC ) Ibu Hamil. Majority. 2017;7(November):72-6. 
UMI Medical Journal Vol.6 Issue:1 (Juni, 2021)

p-ISSN: 2548-4079/e-ISSN: 2685-7561

9. Dewi MK, Widarini W, Karmaya INM. Hubungan Karakteristik Sosial Ekonomi dan Dukungan Suami dengan Kelengkapan Antenatal Care (ANC) di Puskesmas Denpasar Selatan III. Public Heal Prev Med Arch. 2014;2(1):45.

10. Dewi MK. hubungan umur dan pendidikan ibu primigravida dengan kepatuhan kunjungan ANC. Din Kesehat. 2014;5 (4).

11. Fitrayeni F, Suryati S, Faranti RM. Penyebab Rendahnya Kelengkapan Kunjungan Antenatal Care Ibu Hamil Di Wilayah Kerja Puskesmas Pegambiran. J Kesehat Masy Andalas. 2017;10(1):101.

12. Mastiningsih P. Rest Placenta Pada Ibu Nifas P1A1 6 Jam Post Partum Di Ruang Bersalin Rsud Wangaya. J Dunia Kesehat. 2015;5(2):76-86.

13. Junga M, Pondaag L, Kundre R. Faktor-Faktor Yang Berhubungan Dengan Keteraturan Pemeriksaan Antenatal Care (Anc) Ibu Hamil Trimester Iii Di Puskesmas Ranotana Weru Kota Manado. J Keperawatan UNSRAT. 2017;5(1):109332. 